\title{
The role of probiotics and prebiotics in the proper functioning of gut microbiota and the treatment of diseases caused by gut microbiota dysbiosis
}

\author{
Magdalena Frej-Mądrzak ${ }^{1}$, Małgorzata Jeziorek², Jolanta Sarowska ${ }^{1}$, Agnieszka Jama-Kmiecik ${ }^{1}$, \\ Irena Choroszy-Król ${ }^{1}$
}

${ }^{1}$ Department of Basic Medical Sciences, Wroclaw Medical University, Wroclaw, Poland

${ }^{2}$ Department of Dietetics, Wroclaw Medical University, Wroclaw, Poland

\begin{abstract}
Probiotics are live microorganisms, which, if appropriately administered, can beneficially affect human health. Probiotics are used for the prevention and the treatment of many diseases. Beneficial effects of probiotics result from the fact that their presence in the large intestine demonstrates protective properties, whereas their low amount can increase susceptibility to various infections and diseases. Prebiotics are food ingredients that are not digested by endogenous enzymes and selectively pass intact into the large intestine (colon). In this area, they are decomposed by enzymes of beneficial bacteria selectively stimulating the growth and activity of these microbes and having a beneficial effect on human health. Their basic function, which is multiplying beneficial bacteria in the intestine, is associated with the formation of short-chain fatty acids (SCFAs), i.e. butyric, acetic, and propionic acids, fermentation products that occur in the large intestine. The production of such acids results in the decreased intestinal $\mathrm{pH}$ level that maintains the homeostasis of gut microbiota. Using probiotics is recommended due to the fact that they favour the development of normal gut microbiota, which, as a consequence, prevents intestinal diseases and improves the health of the entire organism. Furthermore, probiotics have also been used for therapeutic purposes and, in the case of various disorders, as a factor supporting and stimulating intestinal regeneration during the recovery period.
\end{abstract}

Key words: probiotics, prebiotics, gut microbiota.

\section{Introduction}

Human intestinal microbiota is very diverse and complex, performing many important functions for the proper functioning of the body. The condition of human health depends on favourable and unfavourable effects of commensal and pathological microbiota. Comparing the composition of the microbiota of the gastrointestinal tract of healthy individuals and individuals diagnosed with different diseases, significant differences can be observed in the composition and advantages of pathogenic bacteria inhabiting the gastrointestinal tract, which cause a number of adverse changes inside the body and numerous clinical symptoms. However, the composition of microbiota is individual and depends on many factors, including: demographic, related to the place of residence, diet, as well as external factors and lifestyle factors. The proper intestinal microbiota includes several hundred species of microorganisms. Changes in the composition of microbiota depend not only on environmental factors, such as the place of residence and the way of eating, but also genetic. The intestinal microbiota of a healthy person affects the body based on the principle of commensalism, i.e. benefiting one organism without harming the other or mutual benefits. In healthy conditions the number of individual groups of microorganisms is balanced, and thanks to that it can positively affect the body, at the same time protecting it against diseases. The diversity of bacteria in the gastrointestinal tract allows adaptation to changing environmental conditions, as well as the possibility of rapid growth and stable colonisation, so that they cannot easily be removed from the body. As a result of

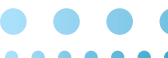

$\bullet \bullet \bullet$ 
the action of various exogenous and endogenous factors, the structure of intestinal microbiota and development of pathogens may change, i.e. dysbiosis. This is related to the change in the number of bacteria, and changes in composition and activity. In this situation, the majority of bacteria are undesirable and potentially pathogenic, manifesting their harmful effects at the time of disturbed homeostasis. Factors affecting intestinal microbiota disorders include the use of antibiotics, improper diet, or colonisation of pathogenic bacteria. Changes in the composition of microbiota are observed in a number of diseases - mainly of the digestive tract, obesity, and cancer, and even neurodegenerative diseases. The presence of prebiotics and probiotics in the intestine affects the proper functioning of the gut microbiota.

\section{Probiotics}

Probiotics are living microorganisms, which, if appropriately administered, can beneficially affect human health [1]. Probiotics are used for the prevention and the treatment of many diseases. The beneficial effects of probiotics result from the fact that their presence in the large intestine demonstrates protective properties, whereas their low amount can increase susceptibility to various infections and diseases [2]. Several types of bacterial strains have been classified as probiotics based on the following conditions: they do not exert adverse effects on the human body; they remain stable in the acidic environment of the stomach and in the alkaline environment of the intestines; and they can colonise the intestine and modify the intestinal immune system [3]. Probiotics primarily include Lactobacillus spp. and Bifidobacterium spp., but also Lactococcus lactis, Enterococcus faecium, Enterococcus faecalis, Bacillus cereus, and Escherichia coli. Saccharomyces boulardii was distinguished among strains of yeast [2]. The most common groups of probiotics are lactic acid bacteria, which include Lactobacillus spp., Bifidobacterium spp., Streptococcus spp., Enterococcus spp., Lactococcus spp., and Leuconostoc spp., which are frequently used to prevent diarrhoea, in the treatment of the effects of lactose intolerance and diarrheal diseases, and for the treatment of peptic ulcers. Probiotics not only stimulate the intestinal and systemic activity of the immune system, exert antifungal activity, and play a role in the prevention of infectious diseases and allergies, but they also affect the incidence of colorectal cancer, slow down the disease progression, and prevent gastric ulcers. Probiotics are also used in food production (mainly of dairy products) and in food storage [4].

Two groups of probiotic bacteria: lactic acid rods, which belong to the Lactobacillus and Bifidobacterium, should also be mentioned. The former are particularly important due to their bacteriostatic function and the abili- ty to modify the immunological intestinal function. Also, they increase the bioavailability of food ingredients by producing appropriate enzymes such as glucose-6-phosphate isomerase, lactate dehydrogenase, and D-xylose 5-phosphate, and they are involved in the synthesis of $B$ vitamins and vitamin $K$ [2]. Lactic acid bacteria have been reported in bio-yoghurts, most commonly Bifidobacterium lactis. Although Lactobacillus have different mechanism of action, they are also characterised by their preventative and protective properties in the large intestine. Their main task, in addition to the production of lactic acid, is to produce bacteriocins and reduce the level of taurocholic acids [2]. There are many arguments suggesting that probiotics should be consumed in foods containing live lactic acid bacteria, i.e. in fermented milk products. Probiotics have a beneficial effect on the digestive tract, such as on moderate symptoms of lactose intolerance, viral diarrhoeas, irritable bowel syndrome, and inflammatory bowel disease, maintaining proper insulin levels in blood, and increasing the intestinal absorption of fatty acids. Lactic acid fermentation products are beneficial because they provide appropriate conditions for the restoration of normal intestinal microbiota, eliminate pathogenic bacteria, and enhance the ability of the intestinal barrier to recognise foreign antigens. Furthermore, they improve the functioning of the immune system by stimulating phagocytosis, activating humoral immunity, and producing anti-inflammatory compounds [4]. Their antagonistic nature against pathogenic bacteria can be indicated by taking into account all probiotic strains occurring in the intestine. This results from the fact that probiotics decrease the intestinal $\mathrm{pH}$ level, inhibit the colonisation and movement of undesired bacteria, and produce antimicrobial substances and antibodies [5]. All the above-mentioned factors create a physiologically restrictive environment that prevents the colonisation of undesired bacteria. The fact that probiotics produce antibacterial substances particularly strengthens their beneficial and protective potential [5]. Lactobacillus acidophilus produce substances against Helicobacter pylori and Enterococcus spp. and antibacterial substances against Listeria monocytogenes [3]. Today, the easiest way of taking probiotics is to consume a proper diet. It has become a common practice of food manufacturers to supplement their products with specially selected probiotic preparations by adding bacteria, using pharmaceuticals or selected vaccines containing microorganisms [2].

\section{Prebiotics}

Prebiotics are food ingredients that are not digested by endogenous enzymes and selectively pass intact into the large intestine (colon). In this area, they are decomposed by enzymes of beneficial bacteria selectively stimulating 
growth and activity of these microbes and having a beneficial effect on human health [3]. Their basic function, which is to multiply beneficial bacteria in the intestine, is associated with the formation of short-chain fatty acids (SCFAs), i.e. butyric, acetic, and propionic acids - fermentation products of fibre. The production of such acids results in the decreased intestinal $\mathrm{pH}$ level that maintains the homeostasis of gut microbiota. An increased bioavailability of minerals is associated with, among others, a reduced intestinal $\mathrm{pH}$ level. Since calcium and magnesium ions become more soluble in an acidic environment, their bioavailability increases. However, inulin-type prebiotics, or resistant starch, significantly increase the bioavailability of calcium, iron, and zinc. The overall increase in the bioavailability of minerals is associated with the fact that the activity of dietary fibre in the large intestine leads to intestinal epithelial hyperplasia, thereby increasing the area of nutrient absorption. The activity of SCFAs is also associated with a reduced number of pathogens in the intestine. Supplying the body with oligosaccharides disrupts the intestinal colonisation with pathogenic strains of Escherichia coli, whereas cellobiose prevents the host from Listeria monocytogenes infections. Due to the fact that SCFAs increase the return resorption of sodium and water, they are beneficial in the treatment of diarrhoea. Moreover, SCFAs stimulate intestinal function and, as a consequence, help in constipation [6]. Prebiotics play an essential role in fighting pathogens, they reduce the risk of infection with Clostridium difficile and the symptoms of travellers' diarrhoea, and alleviate allergy symptoms. In addition, prebiotics act as a therapeutic agent in irritable bowel syndrome and in inflammatory bowel disease [7]. Prebiotics are commonly found in food, particularly in functional foods. To qualify as a prebiotic food, each ingredient should meet necessary criteria. First of all, food should be resistant to digestion by salivary, pancreatic, and intestinal enzymes. Moreover, it can be fermented by gut microbiota, stimulating the growth and activity of intestinal bacteria, which is helpful in maintaining the host's health [8]. Dietary fibre, which consists of structural elements of plant cell walls, can be found in vegetables, fruits, grains, nuts, seeds, and legumes. Dietary fibre commonly includes polysaccharides (cellulose, hemicellulose, pectin's, gums) and non-starch polysaccharides (lignin) [3]. Due to their specific functions, there are two fractions of dietary fibre: soluble and insoluble. Insoluble dietary fibre primarily influences the proper functioning of the digestive tract. By binding water, it increases the volume of gastric content, which, by irritating the large intestinal walls, stimulates peristalsis. Soluble dietary fibre, however, by undergoing bacterial fermentation, delivers energy to colonocytes and relieves the intestinal passage, which is helpful in the treatment of diarrhoea. Moreover, dietary fibre has a beneficial effect on the me- tabolism of lipids [6]. Oligosaccharides and polysaccharides (also prebiotics) are classified as soluble dietary fibre. Oligosaccharides include three main subgroups, i.e. fructooligosaccharides, galactooligosaccharides, and lactulose, with the first two being particularly recognised as prebiotics [6]. Fructooligosaccharides (FOS) are fructose polymers, which include oligofructose, i.e. one of the main prebiotics, which can be found in many foods, such as wheat, chicory, sunchoke, onions, garlic, tomatoes, and bananas. Due to their delicate sweetness, FOS are often used as substitute sweeteners in "light" products. Furthermore, they can be found in fermented milk products. Oligofructose has hygroscopic properties and reduces water activity of products. It is estimated that if 4-15 g of this substance is supplied to the body, the number of $B i$ fidobacteria in faeces increases 5-10 times. This is due to the fact that Bifidobacteria digest fructooligosaccharides, which leads to their growth in the intestine. Moreover, even a short-term diet rich in these components leads to Bifidobacteria dominance in gut microbiota [6]. Galactooligosaccharides (GOS) are the second group of compounds acting as prebiotics. The main source of GOS is fermented dairy products. They can be found in products for children (beverages and functional foods), in sweets, sweeteners, yoghurts, and soft drinks. These compounds are not very sweet, can be dissolved in water, and contain few calories. It is doubtful whether lactulose can be classified as a prebiotic, because it is susceptible to digestion by numerous species of intestinal bacteria, including Lactococcus lactis and Lactobacillus casei. However, lactulose is used as a laxative to treat constipation [6]. The group of polysaccharides includes starch, cellulose, hemicellulose, pectin, inulin, and resistant starch. The latter two are considered prebiotics, which is related to the scope of their functions. Inulin is a food component without any taste or smell. It is used in the food production process because it improves the organoleptic characteristics of products, e.g. produces a gel-like-substance. It can be found, most frequently, in dairy and confectionery products. SCFAs are produced by the fermentation of resistant starch in the colon. The degree of hydrolysis influences the prevailing starch fraction (amylase or amylopectin hydrolysis). Resistant starch can be found in cereal and bread because it is made by exposing starch products to high temperature with a small amount of water [6].

\section{Irritable bowel syndrome}

Irritable bowel syndrome (IBS) is caused by the alteration in the composition of gut microbiota. IBS is a functional bowel disorder that occurs in $10-20 \%$ of the population in developing countries. IBS is characterised by abdominal pain and intestinal discomfort because of the impaired bowel function and frequent bloating that sig- 
nificantly influence the quality of life of people suffering from this disease [9]. Typical symptoms of IBS include abdominal pain that increases after meals, diarrhoea or constipation, bloating, gas, urgency of defecation, and a feeling of incomplete evacuation. Based on the analysis of stool consistency characteristic for the disease, IBS was divided into constipation predominant, diarrhoea predominant, mixed type, and unclassified type [10-12]. It is recommended that IBS therapy is multidisciplinary and includes both pharmacological and non-pharmacological treatment. Pharmacological treatment includes, among others, the application of diastolic and antidiarrhoeal drugs, agents that limit intestinal gas, laxatives (lactulose), and spasmolytic and cholinolytic drugs [10,11]. Non-pharmacological treatment includes changes in lifestyle, nutrition, and psychotherapeutic treatment, as well as education of patients. After being diagnosed with IBS, the first element that should be changed is taking up moderate, individually tailored, physical activity because it has a positive effect on the digestive tract and facilitates defecation. Furthermore, regular exercise reduces stress, which has a significant influence on the development and the course of disease [10-13]. Changing eating habits is essential in IBS treatment. Dietary recommendations depend on the form of the disease. Products that worsen symptoms should be excluded from the diet. In constipation-type IBS, it is recommended to follow high-fibre diet containing 30-50 g of fibre per day, consisting of coarse grains and (mostly raw) fruits and vegetables. Moreover, it is suggested that white bread, sweets, chocolate, flour-based meals, eggs, fat and fried food, alcohol, and carbonated beverages are eliminated. Because fibre stimulates the digestive tract, it significantly helps with constipation, influences stool consistency and volume, and promotes intestinal passage. Hydrated stool reduces the risk of constipation, and, therefore, increased fluid intake is advocated when increasing dietary fibre. The recommended liquids are: still water, diluted beverages, and fermented milk products that have a beneficial effect on gut microbiota [10-13]. In diarrhoea-type IBS, it is recommended that an easily digestible diet be followed, based on food made of white flour, boiled, cooked, and shredded vegetables and fruits. It is recommended that fried, bloating, and heavy foods are eliminated, as well as strong coffee, tea, and alcohol, and fat intake should also be reduced. Because diarrhoea is frequently accompanied with bloating, it is required that consumption of caffeine, fruits, coarse grains, and sorbitol is limited because these products contain an ideal breeding ground for gas-producing bacteria - bicarbonate. Adequate hydration is as important as in constipation-type IBS. Regardless of the IBS type, patients should follow the same rules when it comes to consuming meals, which should be frequent and small. It is recommended that patients eat slowly, regularly, and not later than three hours before bedtime. Food should not be very hot or cold for fear of irritating the digestive tract [10-13]. Probiotics are an increasingly acknowledged element of fighting IBS symptoms. The most commonly used probiotics administered orally are Bifidobacterium, Lactobacillus plantarum, Lactobacillus reuteri, and Lactobacillus rhamnosus, which are believed to reduce bloating and constipation, delay intestinal passage, and reduce abdominal pain and diarrhoea [14].

\section{Small intestinal bacterial overgrowth}

Small intestinal bacterial overgrowth (SIBO) results from an excessive multiplication of mostly anaerobic bacteria in the jejunum due to impaired defence mechanisms in the digestive tract. Moreover, an increased gastric $\mathrm{pH}$ can no longer maintain the appropriate balance between the bacterial colonisation in the stomach and intestines. Disorders of gastric motility play a role in retaining excessive bacteria in the small intestine. Ileocecal valve dysfunction, which causes colonic bacteria to enter the small intestine, as well as an imbalanced secretion of immunoglobulin A ( $\operatorname{Ig} \mathrm{A})$ and mucus, lead to the lack of factors strengthening bacteria and, consequently, to excessive intestinal colonisation $[15,16]$. Typical clinical symptoms include diarrhoea (often watery or fat), gas, bloating, weight loss, and abdominal pain. Other consequences of the disease result from vitamin deficiencies and include, among others, rickets, osteomalacia, tetany, oedema, and neurological changes. Immunological imbalance predisposes to the appearance of parenteral symptoms, i.e. ulcers, erythema, inflammation of osteochondral system, dermatitis, and kidney and liver inflammation [15-17].

\section{Treatment and diet}

The treatment of SIBO is aimed at reducing the excessive number of bacteria in the intestine and includes antimicrobial therapy, supplementation with deficient ingredients, adopting an appropriate diet, and the use of probiotics. Taking into account the diversity of microorganisms whose growth leads to intestinal disorders and diseases, the antimicrobial therapy should be directed against aerobic and anaerobic bacteria, and, therefore, the use of a broad variety of drugs is recommended. Patients are often recommended a diet with limited lactose so as to alleviate common intestinal symptoms. It is necessary to limit dietary fat and, optionally, to administer medium-chain triglycerides fatty acids (MCT). Another important element of the treatment is supplementation with deficient elements such as iron, fat-soluble vitamins, and vitamin B12. In the case of severe weight loss and malnutrition, nutritional supplementation should be considered. Probiotics play an important role in the treatment of the disease, especially Lactobacillus strains, which effec- 
tively help to restore normal bacterial flora after antibiotic treatment and prolong the period of remission [15-17].

\section{Pseudomembranous colitis}

Antibiotic treatment disturbs normal gut microbiota and may lead to pseudomembranous colitis, which is caused by $C$. difficile. The disease most often affects hospitalised patients who, because of the environment, are more likely to acquire C. difficile. Clostridium difficile, after entering the body, multiply and release toxins that lead to diarrhoea and initiate the development of pseudomembranous colitis. Old age, gastrointestinal tract surgeries, chronic inflammatory bowel disease, use of rectal thermometers, and enteral nutrition increase the risk of the disease [18]. The main symptoms, complications, and clinical picture of pseudomembranous colitis, i.e. the most serious form of infection with $C$. difficile, are shown in Table 1.

\section{Treatment}

The treatment of pseudomembranous colitis should begin with the discontinuation of antibiotics that cause symptoms. It is not recommended to use antidiarrhoeals because this prevents the removal of toxins from the gastrointestinal tract. The first-line drug is metronidazole or vancomycin. In addition, the patient shoule be given fluids with electrolytes that are lost in the course of diarrhoea. In order to assist in the recovery after antibiotic therapy, it is recommended to use probiotics, e.g. Saccharomyces boulardii or Lactobacillus rhamnosus GG. If the pharmacological treatment is not effective, colectomy is performed [19-21].

\section{Faecal microbiota transplant}

In the subsequent relapses of the disease, faecal microbiota transplant (FMT) is yet another therapeutic option. This method of treatment is recommended if the standard therapy has failed. FMT is an alternative treatment for patients infected with $C$. difficile and involves inoculation of new bacteria from a healthy donor so as to restore normal microbiota, intestinal function, and health. Donors who qualify for FMT are often related to the recipient. FMT can be performed in repeatedly hospitalised patients aged 60-95 years, with comorbid conditions such circulatory and respiratory insufficiency, chronic kidney disease, cancer, radiotherapy, and steroids. Numerous clinical cases confirm that faecal transplantation is successful in the treatment of relapsing infections with $C$. difficile. FMT is the easiest way to completely change the composition of gut microbiota. Commensal bacteria from a healthy donor are transplanted by infusion of the liquid stool suspension. Bacteria derived from a donor quickly colonise the new location and act as dominant microbio-
Table 1. Complications and clinical picture of pseudomembranous colitis

\begin{tabular}{|l|c|}
\hline Clinical picture & Complications \\
\hline Watery-mucosal diarrhoea & $\begin{array}{c}\text { Paralytic intestinal } \\
\text { obstruction }\end{array}$ \\
\hline Spastic abdominal pain & Toxic colon dilatation \\
\hline Fever, chills & Sepsis \\
\hline $\begin{array}{l}\text { Rapidly increasing } \\
\text { dehydration symptoms }\end{array}$ & Toxaemia \\
\hline Electrolyte disturbance & Peritonitis \\
\hline Hypoalbuminaemia & Intestinal perforation \\
\hline Metabolic acidosis & Septic shock \\
\hline Toxaemia & Hypotonia \\
\hline $\begin{array}{l}\text { High leukocytosis or } \\
\text { leukopaenia }\end{array}$ & $\begin{array}{c}\text { Death, with a severe course } \\
\text { of the disease }\end{array}$ \\
\hline Elevated creatinine levels
\end{tabular}

ta. After introducing new bacteria into the large intestine, they soon occupy niches and restore a healthy intestinal ecosystem. Therefore, symptoms associated with $C$. difficile infection are resolved [22,23]. FMT comprises several stages. After obtaining written, informed consent from a donor to harvest material for a transplant and research, faeces is subjected to tests identifying potential hepatitis $\mathrm{A}$, hepatitis $\mathrm{B}$, hepatitis $\mathrm{C}$, human immunodeficiency virus (HIV), syphilis, cytomegalovirus (CMV), and Epstein-Barr virus (EBV). Then, faecal examination is performed for parasites, C. difficile, and other pathogens or their toxins. Additionally, a donor should not have been subjected to antimicrobial therapy within the last three months. Written, informed consent is also required from the recipient so as to perform surgery and administer antibiotics immediately before the procedure. The harvested material is administered with a colonoscopy, or gastric or duodenal probe. Seven days after the procedure, the control test is performed so as to check the recipient's faeces. FMT is extremely effective in treating patients with diseases caused by $C$. difficile, in whom other therapies have already failed. The risk of disease relapse or death is uncommon after such a procedure. What is more, this method has been proven effective also in the treatment of other gastrointestinal disorders [23].

\section{Inflammatory bowel diseases}

Crohn's disease (CD) and ulcerative colitis are chronic types of inflammatory bowel disease (IBD) of unknown aetiology. The course of these diseases includes periods of predominantly acute exacerbation and remission. Factors 
involved in the pathogenesis of IBD and its complications include disorders of gut microbiota. Preventing pathological changes in microbiota promotes the treatment and maintains the remission [24]. IBS symptoms vary and depend on its type, which is due to, among others, differences in the location of the disease. Characteristic ulcerative colitis symptoms include bloody diarrhoea, increased body temperature, weakening of the body, as well as deficiencies of protein, vitamin B12, B9, iron, calcium, and zinc [24].

\section{Treatment}

Inflammatory bowel disease treatment usually involves pharmacological therapy, with steroids and methotrexate used most frequently. Appropriate nutritional support is significant during the treatment, because it not only supports and keeps IBD in remission as long as possible, but also prevents the consequences of severe nutritional deficiencies. In remission, the diet should not significantly deviate from the diet of healthy individuals, except for some modifications. The most important recommendation is to eat foods low in fibre and easily digested. Moreover, patients should use appropriate methods of food heat-treatment, avoid fat and frying, but also exclude all bloating, gas-causing, and hard-to-digest foods. The temperature of consumed food should be neither too high nor too low, so as not to irritate the digestive tract. The diet should provide all components, especially those significantly deficient, such as vitamins A, D, E, K, and B12, folic acid, and minerals: iron, calcium, potassium, magnesium, zinc, and selenium. An additional element of the IBS diet is the supplementation with deficit ingredients, whose absorption has been significantly impaired or which, due to dietary restrictions, cannot be ingested in the standard diet [24,25].

\section{Faecal microbial transplant}

More and more studies emphasise the importance of faecal microbial transplant (FMT) as a method of treatment in IBD and C. difficile infection. After performing FMT, the number of pathogenic bacteria significantly reduces, whereas commensal strains of Bacteroides species increase. The gut microbiota becomes almost identical as in the healthy donor. It has been proven that FMT frequently leads to the disease remission and to the relief of symptoms [26].

\section{Conclusions}

The diseases listed above indicate that the dysbiosis of gut microbiota can have a significant impact on their pathogenesis or pathological mechanism. Clarifying the relationship between the proper and disturbed functioning of gut microbiota allows for understanding the mech- anisms responsible for the disease. Many environmental factors, such as lifestyle, daily diet, and exercise, contribute to the disorders in the composition and functioning of gut microbiota. It is, therefore, vital to support gut microbiota every day by leading an appropriate lifestyle and adopting a proper diet. Using probiotics is recommended due to the fact that they favour the development of normal gut microbiota, which, as a consequence, prevents intestinal diseases and improves the health of the entire organism. Furthermore, probiotics have also been used for therapeutic purposes, and in the case of various disorders as a factor supporting and stimulating intestinal regeneration during the recovery period $[1,4,6,27]$.

\section{Disclosure}

The authors report no conflict of interest.

\section{References}

1. Rajilić-Stojanović M. Function of the microbiota. Best Pract Res Cl Ga 2013; 27: 5-16.

2. Steinka I. Wybrane aspekty stosowania probiotyków. Ann Acad Med Gedan 2011; 41: 97-108.

3. Górska S, Jarząb A, Gamian A. Bakterie probiotyczne w przewodzie pokarmowym człowieka jako czynnik stymulujący układ odpornościowy. Postepy Hig Med Dosw 2009; 63: 653-667.

4. Masood MI, Qadir MI, Shirazi JH, et al. Beneficial effects of lactic acid bacteria on human beings. Crit Rev Microbiol 2011; 37: 91-98.

5. Harzallah D, Belhadj H. Lactic acid bacteria as probiotics: characteristics, selection criteria and role in immunomodulation of human Gl muccosal barrier. http://dx.doi.org/10.5772/50732 [accessed: 27.02.2015].

6. Kordyl M, Libudzisz Z. Mikroflora jelitowa - znaczenie i modulacja. Żyw Człow Metab 2006; 33: 266-278.

7. Rastall RA, Gibson GR. Recent developments in prebiotics to selectively impact beneficial microbes and promote intestinal health. Curr Opin Biotech 2015; 32: 42-46.

8. Scheid MMA, Moreno YMF, Junior MRM, et al. Effect of prebiotics on the health of the elderly. Food Res Int 2013; 53: 426-432.

9. Staudacher HM, Lomer MCE, Anderson JL, et al. Fermentable carbohydrate restriction reduces luminal Bifidobacteria and gastrointestinal symptoms in patients with irritable bowel syndrome. J Nutr 2012; 142: 1510-1518.

10. Mulak A, Waszczuk E. Zaburzenia czynnościowe jelit, zespół jelita nadwrażliwego. In: Paradowski L (ed.). Zaburzenia czynnościowe przewodu pokarmowego. Cornetis, Wrocław 2012; 105-117.

11. Owyang CH. Zespół jelita nadwrażliwego. In: Rydzewska G (ed.). Gastroenterologia i hepatologia. Vol. 1. Czelej, Lublin 2012; 233240.

12. Jarosz M, Respondek W, Traczyk I. Choroby jelit - zespół jelita nadwrażliwego. In: Jarosz M (ed.). Praktyczny podręcznik dietetyki. Instytut Żywności i Żywienia, Warszawa 2010; 189-195.

13. Gugała-Mirosz S. Zespót jelita nadwrażliwego - leczenie multidyscyplinarne. Żyw Człow Metab 2013; 40: 47-53.

14. Gugała-Mirosz S. Wpływ różnych składników żywności na dolegliwości zespołu jelita drażliwego. Żyw Człow Metab 2013; 40: 39-45.

15. Mrukowicz JZ. Choroby jelita cienkiego - zespół przerostu flory bakteryjnej jelita cienkiego. In: Konturek SJ (ed.). Gastroenterologia i hepatologia kliniczna. Vol. 5. PZWL, Warszawa 2006; 270-271.

16. Anderson MA. Zaburzenia czynności motorycznej oraz nadmierny rozrost flory bakteryjnej w jelicie cienkim. In: Hasler WL, 
Inadomi JM, Anderson MA. Podręcznik gastroenterologii. Czelej, Lublin 2006; 357-360.

17. DiBaise JK. Nutritional consequences of small intestinal bacterial overgrowth. Pract Gastroenterol 2008; 12: 15-28.

18. Gerding DN. Choroba związana z zakażeniem Clostridium difficile wraz z rzekomobłoniastym zapaleniem jelit. In: Rydzewska G (ed.). Gastroenterologia i hepatologia. Vol. 1. Czelej, Lublin 2012; 283-287.

19. Welge I, Rosien U, Melle U, et al. Rzekomobłoniaste zapalenie jelita grubego, zapalenie jelita grubego związane $z$ antybiotykoterapią. In: Paradowski L (ed.). Gastroenterologia praktyczna. Vol. 1. Elsevier Urban \& Partner, Wrocław 2013; 264-267.

20. Olczak A, Grąbczewska E. Rzekomobłoniaste zapalenie jelit o etiologii Clostridium difficile. Przegl Epidemiol 2012; 66: 59-65.

21. Hryniewicz W, Martirosian G, Ozorowski T. Zakażenia Clostridium difficile, diagnostyka, terapia, profilaktyka, Narodowy Program Ochrony Antybiotyków. Ministerstwo Zdrowia, Warszawa 2011; 1-16.

22. Khoruts A, Sadowsky MJ. Therapeutic transplantation of the distal gut microbiota. Mucosal Immunol 2011; 1: 4-7.

23. Gough E, Shaikh H, Manges AR. Systematic review of intestinal microbiota transplantation (fecal bacteriotherapy) for recurrent Clostridium difficile infection. Clin Infect Dis 2011; 53: 994-1002.

24. Jarosz M, Kożuch M. Wrzodziejące zapalenie jelita grubego, choroba Leśniowskiego-Crohna. In: Jarosz M (ed.). Praktyczny podręcznik dietetyki. Instytut Żywności i Żywienia, Warszawa 2010; 242-248.

25. Kożuch M. Rola żywienia w leczeniu choroby Leśniowskiego-Crohna. Żyw Człow Metab 2013; 40: 95-101.

26. Colman RJ, Rubin DT. Fecal microbiota transplantation as therapy for inflammatory bowel disease: A systematic review and meta-analysis. J Crohns Colitis 2014; 8: 1569-1581.

27. Olszewska J, Jagusztyn-Krynicka EK. Human microbiome project - mikroflora jelit oraz jej wpływ na fizjologię i zdrowie człowieka. Post Mikrobiol 2012; 51: 243-256. 